\title{
Delaying Effect of Polyherbal Formulation on Cataract in STZ-NIC-induced Diabetic Wistar Rats
}

\author{
K. K. MALI* SUCHETA S. LIGADE AND R. J. DIAS ${ }^{2}$
}

Department of Pharmaceutics, YSPM'S Yashoda Technical Campus, Faculty of Pharmacy, Wadhephata, Satara-415 011 , ${ }^{1}$ Department of Pharmacology, Sant Gajanan Maharaj College of Pharmacy, Gadhinglaj, Kolhapur-416 503, India, ${ }^{2}$ Department of Pharmacy, Government Polytechnic, National Highway No 6, Jalgaon-425 002, India

\section{Mali et al.: Effect of Polyherbal Formulation on Diabetic Cataract}

\begin{abstract}
The aim of the study was to evaluate the effectiveness of polyherbal formulation on cataract development in streptozotocin-nicotinamide-induced diabetic rats. Diabetes was induced by streptozotocin (65 mg/kg, ip) and nicotinamide $(90 \mathrm{mg} / \mathrm{kg}$, ip). The diabetic rats were orally treated with polyherbal formulation (therapeutic dose, $28.71 \mathrm{mg} / \mathrm{kg}$ and $2 \mathrm{X}$ therapeutic dose, $57.42 \mathrm{mg} / \mathrm{kg})$ and metformin $(150 \mathrm{mg} / \mathrm{kg})$, for $12 \mathrm{weeks}$. Serum glucose levels, body weight, histopathology of pancreas were used to evaluate the antidiabetic activity while the histopathological study of eye and protein content in lens were used to evaluate the protective effect of polyherbal formulation on cataract development. The progression of cataract in rat lens was observed with a slit-lamp biomicroscope. A daily treatment of polyherbal formulation for 12 weeks resulted in significant $(\mathbf{p}<\mathbf{0 . 0 5})$ decrease in serum glucose level, body weight and improved protein content in the lens. It also delayed the incidence of cataract in diabetic rats. The histopathological study showed that there was regeneration of pancreatic $\beta$-cells. The results observed with polyherbal formulation were found to be comparable to those obtained with metformin. Results suggested that the polyherbal formulation possessed antidiabetic activity and prevented cataract development.
\end{abstract}

Key words: Cataract, streptozotocin, nicotinamide, polyherbal, antidiabetic

Diabetes mellitus (DM) is a chronic disease characterized by disorders in carbohydrate, fat and protein metabolism ${ }^{[1]}$. The number of patients with DM is predicted to increase globally to 200 million within the next few years ${ }^{[2]}$. World Health Organization reports showed that 32 million people had diabetes in the year 2000 in India and now 422 million adults are living with diabetes according to the latest 2016 data $^{[3,4]}$.

The cause of significant mortality in diabetes is due to the development of secondary complications ${ }^{[5]}$. DM leads to the development of both microvascular complications like retinopathy, cataract, nephropathy, and macrovascular complications like atherosclerosis, high blood pressure, heart attack and stroke ${ }^{[6]}$.

In the present study, the effect of a polyherbal formulation was studied on one of diabetic complications, the cataract. It is clouding of the crystalline lens of the eye or in its envelope ${ }^{[7]}$. As the extracellular glucose diffuses into the lens, it is the most affected body part in diabetes ${ }^{[8]}$. The mechanism of cataract involves generation of free oxygen radicals, which causes direct modification of the inner lens proteins, such as cross-linking, aggregation, precipitation contributing to yield opacity and leading to cataract ${ }^{[6]}$. Now a days cataract is the major cause of blindness and surgery is the only available solution ${ }^{[9]}$. The prevention of opacification or delays in the development of cataract remains a challenge ${ }^{[10]}$.

Many anticataractogenic agents are available, but due to lack of success in patients, no drug has yet been approved for clinical use ${ }^{[11]}$. There are many herbal products and polyherbal formulations with known anticataract activity such as Ocimum sanctum, Curcuma longa, Azadirachta indica and Diabecon $400^{[12]}$, Okudiabet ${ }^{[13]}$, Diashis ${ }^{[14]}$ and Glycoherb ${ }^{[15]}$. Hence, the present study was undertaken to evaluate

This is an open access article distributed under the terms of the Creative Commons Attribution-NonCommercial-ShareAlike 3.0 License, which allows others to remix, tweak, and build upon the work non-commercially, as long as the author is credited and the new creations are licensed under the identical terms

Accepted 14 March 2019

Revised 21 November 2018

Received 21 February 2017

Indian J Pharm Sci 2019;81(3):415-423 
one such polyherbal formulation composed of six different herbal extracts. The composition of polyherbal formulation is given in Table 1. This formulation available in the market has been proved to be effective in diabetes, but there is no data available whether this polyherbal formulation is effective in preventing diabetic complications. Therefore, an attempt was made to evaluate its effectiveness in delaying cataract development.

\section{MATERIALS AND METHODS}

Streptozotocin (STZ) was procured from Chemvenio, LIC, Gulbarga, India. Nicotinamide (NIC) was procured from Lasons India Ltd, Taloja, Raigad, India and the polyherbal formulation was supplied by Nisarga Biotech, Pvt. Ltd., Satara, India.

\section{Experimental animals:}

Forty male Wistar rats (180-200 g) were procured from Shri Venkateshwara Enterprises, Bangalore, India and were housed in the animal house of Satara College of Pharmacy, Satara, India at a temperature of $25 \pm 1^{\circ}$ and humidity $(45 \pm 5 \%)$ with a 12:12 h day:night cycle. Animals were kept in polypropylene cages with a stainless steel lid with free access to standard pelleted diet and water ad libitum. The studies were carried out in the Pharmacology Department of Satara College of Pharmacy. The experimental protocol was approved by the Institutional Animal Ethics Committee of Satara College of Pharmacy, Satara (SCOP/IAEC/017/11-12) and it was carried out according to the Committee for the Purpose of Control and Supervision on Experiments on Animals guidelines for laboratory animal facility.

\section{Acute toxicity studies:}

Acute oral toxicity of the polyherbal formulation was carried out as per the guidelines set by the Organization for Economic Co-operation and Development revised draft guidelines 423. Healthy Wistar rats (3 animals/ dose) of either sex were used in this study. Rats were fasted overnight and orally fed with the polyherbal formulation in increasing dose levels of 5, 50, 300, and $2000 \mathrm{mg} / \mathrm{kg}$. These rats were observed for behavioural (alertness, restlessness, irritability and fearfulness), neurological (spontaneous activity, reactivity, touch response, pain response and gait) and autonomic (defecation and urination) symptoms continuously for $24 \mathrm{~h}$. After a period of $24 \mathrm{~h}$, the animals were observed for the next $14 \mathrm{~d}$ for mortality.
TABLE 1: COMPOSITION OF POLYHERBAL FORMULATION

\begin{tabular}{lcc}
\hline Ingredients & Botanical name & Quantity \\
\hline Guduchi & Tinospora cardifolia & $35 \mathrm{mg}$ \\
Dalchini & Cinnamomum zeylanicum & $50 \mathrm{mg}$ \\
Haridra & Curcuma longa & $48 \mathrm{mg}$ \\
Methika & Trigonella foenum-graecum & $180 \mathrm{mg}$ \\
Nimba & Azadirachta indica & $4 \mathrm{mg}$ \\
Maricha & Piper nigrum & $2 \mathrm{mg}$ \\
Excipient & - & qs
\end{tabular}

\section{Induction of experimental diabetes:}

Rats were fasted for $16 \mathrm{~h}$ and NIC $(90 \mathrm{mg} / \mathrm{kg}$ ) was administered through intraperitoneal route. After $15 \mathrm{~min}$ of administration of NIC, STZ (65 mg/kg, ip) was injected. STZ is capable of inducing fatal hypoglycaemia as a result of massive pancreatic insulin release, therefore, the rats were provided with $10 \%$ glucose solution after $6 \mathrm{~h}$ of STZ administration for the next $24 \mathrm{~h}$ to prevent hypoglycaemia. Mortality or any other adverse effects were closely monitored. After allowing a week's time for the development and aggravation of diabetes, rats with moderate diabetes (i.e. blood glucose concentration $>200 \mathrm{mg} / \mathrm{dl}$ ) that exhibited glycosuria and hyperglycaemia were selected for the experiment $t^{[16]}$.

\section{Experimental design:}

After inducing experimental diabetes, rats were divided into five groups, each comprising a minimum of eight rats. Carboxymethyl cellulose $(\mathrm{CMC} ; 0.1 \% \mathrm{w} / \mathrm{v})$ in distilled water was used as the vehicle. Polyherbal formulation at doses of 28.71 and $57.42 \mathrm{mg} / \mathrm{kg}$ was suspended in vehicle and administered to treatment groups orally every day for $12 \mathrm{w}$. These 5 groups of rats consisted of normal control group, normal rats administered with $0.1 \% \mathrm{CMC}(1.25 \mathrm{ml} / \mathrm{kg} /$ day, po); diabetic control group, STZ-NIC-induced diabetic rats, administered with $0.1 \% \mathrm{CMC}(1.25 \mathrm{ml} / \mathrm{kg} /$ day, po); standard treated group, diabetic rats administered with metformin $(150 \mathrm{mg} / \mathrm{kg} / \mathrm{day}$, po) for $12 \mathrm{w}$; therapeutic dose group, diabetic rats administered with a therapeutic dose of polyherbal formulation $(28.71 \mathrm{mg} / \mathrm{kg} /$ day, po) for $12 \mathrm{w}$. The therapeutic dose was calculated from human dose of polyherbal formulation, which was $319 \mathrm{mg}$ for an adult of $70 \mathrm{~kg}$ and converted it to animal dose based on no observable adverse effect level (NOAEL $)^{[17,18]}$. Diabetic rats administered with $2 \mathrm{X}$ therapeutic dose of polyherbal formulation $(57.42 \mathrm{mg} /$ $\mathrm{kg} /$ day, po) for $12 \mathrm{w}$ to check the effectiveness of a higher dose. 


\section{Evaluation of antidiabetic activity:}

Serum glucose level and body weight was measured weekly. The dosage was adjusted weekly according to any change in body weight to maintain similar dose per $\mathrm{kg}$ body weight of rat over the entire period of study for each group. The survived animals from each group after $12 \mathrm{w}$ were euthanized by sodium pentobarbital, with a dose of $200 \mathrm{mg} / \mathrm{kg}$ injection followed by cervical dislocation and each rat was utilized to test for histopathology of pancreas, one eye was used for histopathological studies and other eye for protein determination $^{[19]}$.

\section{Evaluation of cataract development:}

Rats were lightly anaesthetized with ether for assessing cataract progression by observing the rat lens with a slitlamp biomicroscope in Drishti Eye Hospital, Satara. Pupil of rats was dilated by instillation 2 to 3 drops of Tropicacyl Plus ${ }^{\circledR}$ (tropicamide $0.8 \%$ and phenylephrine $5 \%$ ) in the conjuctival sac of each eye. Tropicacyl was added prior to ophthalmic examination ${ }^{[20]}$. Lenticular changes were observed in each month. The progression of cataract observed during slit lamp examination is mentioned as follows, as per grading scale ${ }^{[21]}$; stage 0: clear lenses and no vacuoles present; stage 1: vacuoles cover approximately one half of the surface of the anterior pole, forming a subcapsular cataract; stage 2: some vacuoles disappeared and cortex exhibits a hazy opacity; stage 3: a hazy cortex remained and dense nuclear opacity present; stage 4: a mature cataract, dense opacity in both cortex and nucleus.

\section{Estimation of total protein of eye lens:}

For estimation of total proteins, the eyes were enucleated and the lenses were dissected separately ${ }^{[22]}$. One dissected lens was homogenized in $4.0 \mathrm{ml}$ deaerated phosphate buffer saline $(\mathrm{pH}$ 7.3) using a homogenizer. The lens homogenate was dialyzed for $24 \mathrm{~h}$ and centrifuged for $2 \mathrm{~h}$ at $4^{\circ}$ at $13500 \mathrm{rpm}$. Protein content of the supernatant was determined using Biuret method kit (Rackon diagnostics, India) ${ }^{[23]}$.

\section{Histopathology of pancreas and eye:}

The pancreas and eyes of animals were removed and fixed in $10 \%$ formalin. Then they were embedded in paraffin. Organ sectioning was carried out on a microtome, sections were stained with haematoxylin and eosin and observed for histopathological changes under microscope ${ }^{[21]}$.

\section{Statistical analysis:}

Data were expressed as mean \pm SE (standard error). Statistical analysis was done by using one way analysis of variance followed by Tukey's Multiple Comparison Test by using GraphPad Prism software. $\mathrm{P}<0.05$ was considered as the minimal level of statistical significance.

\section{RESULTS AND DISCUSSION}

Acute toxicity studies did not show any mortality up to $2000 \mathrm{mg} / \mathrm{kg}$ given as single oral administration. Hence, the study was carried out at the dose levels of $28.71 \mathrm{mg} / \mathrm{kg}$ and $57.42 \mathrm{mg} / \mathrm{kg}$. Diabetes was induced in 40 rats using STZ (65 mg/kg, ip) and NIC (90 mg/kg, ip). All animals from normal control group were alive till the end of the experiment. About $50 \%$ of diabetic rats died from the diabetic control group, $12.5 \%$ of diabetic rats died from standard group treated with metformin while $25 \%$ of diabetic rats died in both therapeutic and $2 \mathrm{X}$ therapeutic dose of polyherbal formulation-treated group. The mortality rate in metformin and polyherbal formulation-treated group was less as compared to diabetic control group.

The effect of polyherbal formulation as well as metformin treatment on the blood glucose concentration in control and experimental groups of rats is shown in Table 2. There was an increase in serum glucose level in diabetic control group after administration of STZ-NIC intraperitoneally. The serum glucose level decreased significantly $(\mathrm{p}<0.05)$ after oral administration of metformin $(91.4 \%)$, therapeutic $(82.5 \%)$ and $2 \mathrm{X}$ therapeutic dose $(87.51 \%)$ of polyherbal formulation when compared with diabetic control group.

Change in the body weights of all 5 groups of animals during the course of study is given in Table 3. There was significant $(p<0.05)$ decrease in the body weight of diabetic rats from control group compared to that of normal rats. In diabetic control rats, the weight loss was about $51.85 \%$ at the end of study. However, this significant weight loss was prevented in diabetic rats orally treated with metformin as well as polyherbal formulation. The weight loss was reduced in metformintreated group approximately by $7 \%$ whereas in the groups treated with therapeutic dose of polyherbal formulation and $2 \mathrm{X}$ therapeutic dose of polyherbal formulation, the weight loss reduction was found to be 2 and $3 \%$, respectively. 
TABLE 2: EFFECT OF METFORMIN AND POLYHERBAL FORMULATION TREATMENT ON SERUM GLUCOSE

\begin{tabular}{|c|c|c|c|c|c|}
\hline \multirow{2}{*}{$\begin{array}{l}\text { Name of } \\
\text { group }\end{array}$} & \multirow{2}{*}{ Treatment given } & \multicolumn{4}{|c|}{ Time interval (weeks) } \\
\hline & & 0 & 4 & 8 & 12 \\
\hline $\begin{array}{l}\text { Normal } \\
\text { control }\end{array}$ & $\begin{array}{c}0.1 \% \text { CMC } \\
(1.25 \mathrm{ml} / \mathrm{kg})\end{array}$ & $\begin{array}{c}103.7 \pm 3.99 \\
(n=8)\end{array}$ & $\begin{array}{c}106.5 \pm 4.13 \\
(n=8)\end{array}$ & $\begin{array}{c}106.6 \pm 2.8 \\
(n=8)\end{array}$ & $\begin{array}{c}107.9 \pm 3.6 \\
(n=8)\end{array}$ \\
\hline $\begin{array}{l}\text { Diabetic } \\
\text { control }\end{array}$ & $\begin{array}{c}0.1 \% \mathrm{CMC} \\
(1.25 \mathrm{ml} / \mathrm{kg})\end{array}$ & $205.1 \pm 12.94^{\#}(n=8)$ & $255.5 \pm 6.02^{\#}(n=6)$ & $\begin{array}{c}301 \pm 10.39^{\#} \\
(n=5)\end{array}$ & $348.3 \pm 11.4^{\#}(n=4)$ \\
\hline Standard & $\begin{array}{l}\text { Metformin }(150 \mathrm{mg} / \\
\mathrm{kg})\end{array}$ & $\begin{array}{c}203.4 \pm 12.62 \\
(n=8)\end{array}$ & $\begin{array}{c}162.9 \pm 12.85 \\
(n=8)\end{array}$ & $\begin{array}{c}137.9 \pm 11.23^{\dagger} \\
(n=7)\end{array}$ & $\begin{array}{c}112.6 \pm 8.549^{\dagger} \\
(n=7)\end{array}$ \\
\hline $\begin{array}{l}\text { Therapeutic } \\
\text { dose }\end{array}$ & $\begin{array}{c}\text { Polyherbal } \\
\text { formulation }(28.71 \\
\mathrm{mg} / \mathrm{kg})\end{array}$ & $\begin{array}{l}207.8 \pm 7.078 \\
\quad(n=8)\end{array}$ & $\begin{array}{c}177 \pm 6.61^{\dagger} \\
(\mathrm{n}=7)\end{array}$ & $\begin{array}{c}153.9 \pm 7.01^{\dagger} \\
(n=7)\end{array}$ & $\begin{array}{c}127.2 \pm 7.45^{\dagger} \\
(n=6)\end{array}$ \\
\hline $\begin{array}{l}2 \mathrm{X} \\
\text { Therapeutic } \\
\text { dose }\end{array}$ & $\begin{array}{c}\text { Polyherbal } \\
\text { formulation }(57.42 \\
\mathrm{mg} / \mathrm{kg})\end{array}$ & $\begin{array}{c}205.5 \pm 10.74 \\
(n=8)\end{array}$ & $\begin{array}{c}173.2 \pm 10.28^{\dagger} \\
(n=7)\end{array}$ & $\begin{array}{c}148.3 \pm 12.54 \\
(n=6)\end{array}$ & $\begin{array}{c}119.4 \pm 11.23^{\dagger} \\
(n=6)\end{array}$ \\
\hline
\end{tabular}

Values are expressed as mean ${ }_{\mathrm{SEM}}$ (standard error of the mean) $\mathrm{n}$ is the number of animals. Serum glucose is given in $\mathrm{mg} / \mathrm{dl}$. Statistical analysis is one way ANOVA followed by Tukey's multiple comparison test. $\mathrm{P}<0.05$ was considered statistically significant; \#data compared with normal control; ${ }^{\dagger}$ data compared with diabetic control

TABLE 3: EFFECT OF METFORMIN AND POLYHERBAL FORMULATION TREATMENT ON BODY WEIGHT

\begin{tabular}{|c|c|c|c|c|c|}
\hline \multirow{2}{*}{ Name of group } & \multirow{2}{*}{ Treatment given } & \multicolumn{4}{|c|}{ Time interval (weeks) } \\
\hline & & 0 & 4 & 8 & 12 \\
\hline Normal control & $\begin{array}{c}0.1 \% \text { CMC } \\
(1.25 \mathrm{ml} / \mathrm{kg})\end{array}$ & $\begin{array}{l}204.5 \pm 3.13 \\
(n=8)\end{array}$ & $\begin{array}{l}215.9 \pm 2.41 \\
(\mathrm{n}=8)\end{array}$ & $\begin{array}{l}228.3 \pm 2.71 \\
(n=8)\end{array}$ & $\begin{array}{c}242 \pm 2.62 \\
(n=8)\end{array}$ \\
\hline Diabetic control & $\begin{array}{c}0.1 \% \mathrm{CMC} \\
(1.25 \mathrm{ml} / \mathrm{kg})\end{array}$ & $\begin{array}{c}175.2 \pm 6.54^{\#} \\
(n=8)\end{array}$ & $\begin{array}{c}159.9 \pm 9.06^{\#} \\
(n=6)\end{array}$ & $\begin{array}{l}145.0 \pm 3.24^{\#} \\
(n=5)\end{array}$ & $\begin{array}{c}125.5 \pm 5.17^{\#} \\
(n=4)\end{array}$ \\
\hline Standard control & Metformin (150 mg/kg) & $\begin{array}{c}170.3 \pm 5.88 \\
(n=8)\end{array}$ & $\begin{array}{l}188.3 \pm 4.53^{\dagger} \\
(n=8)\end{array}$ & $\begin{array}{c}201.7 \pm 2.36^{\dagger} \\
\quad(n=7)\end{array}$ & $\begin{array}{c}218.4 \pm 2.58^{\dagger} \\
\quad(n=7)\end{array}$ \\
\hline Therapeutic dose & $\begin{array}{l}\text { Polyherbal formulation }(28.71 \mathrm{mg} / \\
\mathrm{kg})\end{array}$ & $\begin{array}{c}166.1 \pm 4.4 \\
(n=8)\end{array}$ & $\begin{array}{c}172.0 \pm 4.43 \\
(n=7)\end{array}$ & $\begin{array}{c}188.9 \pm 5.25^{\dagger} \\
(n=7)\end{array}$ & $\begin{array}{c}203.1 \pm 9.05^{\dagger} \\
(n=6)\end{array}$ \\
\hline $2 X$ Therapeutic dose & $\begin{array}{l}\text { Polyherbal formulation }(57.42 \text { mg/ } \\
\text { kg) }\end{array}$ & $\begin{array}{c}172.8 \pm 5.04 \\
(n=8)\end{array}$ & $\begin{array}{c}180.3 \pm 5.6 \\
(n=7)\end{array}$ & $\begin{array}{c}196.5 \pm 7.81^{\dagger} \\
(n=6)\end{array}$ & $\begin{array}{c}211.4 \pm 10.04^{\dagger} \\
(n=6)\end{array}$ \\
\hline
\end{tabular}

Values are expressed as mean \pm SEM. Statistical analysis by one way ANOVA followed by Tukey's multiple comparison test. $\mathrm{P}<0.05$ was considered statistically significant; "data compared with normal control; ${ }^{\dagger}$ data compared with diabetic control

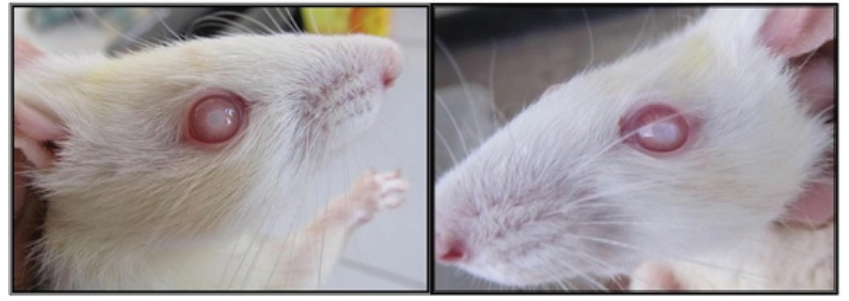

Fig. 1: Rats with cataract

Cataracts were developed in the eyes of STZ-NICtreated rats throughout the experimental period. The development of cataract and different stages of development are shown in the figs. 1 and 2. All lenses in the normal control group and standard group treated with metformin were clear throughout the study with no opacification. The onset of cataract in the diabetic control group was observed from the 3rd w of STZNIC injection. At the end of 12 th w, $50 \%$ lenses were in the 4 th stage, $50 \%$ lenses were in $3 \mathrm{rd}$ stage in the diabetic control group. Whereas onset of cataract in the polyherbal-treated group was observed from 10 th $\mathrm{w}$ in case of therapeutic dose and from 12th w group in case

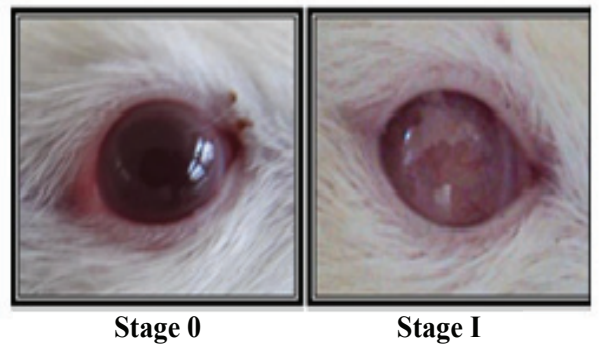

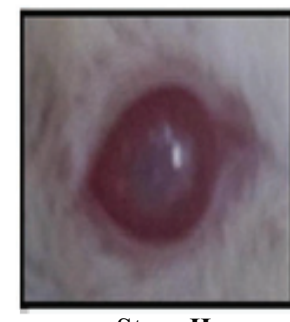

Stage II

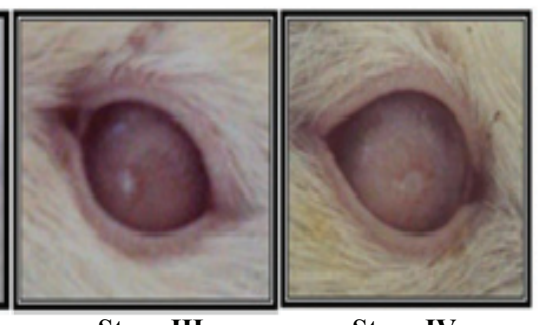

Stage III
Stage IV
Fig. 2: Stages of cataract development

of $2 \mathrm{X}$ therapeutic dose. The progression of cataract was slower in rats treated with therapeutic and $2 \mathrm{X}$ therapeutic dose of polyherbal formulation. At the end 12 th w, $12.5 \%$ of lenses of therapeutic dose were in 
the 2 nd stage and $12.5 \%$ lenses of $2 \mathrm{X}$ therapeutic dose were in the 1 st stage as shown in the fig. 3 .

The lens is made of mostly water and protein. Denaturation of proteins leads to lens opacification. Therefore, total protein content was analysed in all groups and the results are given in Table 4 . The content of protein observed at the end of study in normal control rat was $1.02 \mathrm{~g} / \mathrm{dl}$, while in the diabetic control group it was $0.27 \mathrm{~g} / \mathrm{dl}$. Protein content was found to be significantly normal i.e. $0.91 \mathrm{~g} / \mathrm{dl}$ in case of rats treated with metformin. While in rats treated with therapeutic dose and $2 \mathrm{X}$ therapeutic dose the protein content was 0.66 and $0.73 \mathrm{~g} / \mathrm{dl}$, respectively.

The results of histopathological examination of pancreas are shown in fig. 4. Fig. 4A showed normal acinar pattern and islet cells in normal control. There was no inflammation and fibrosis. Fig. 4B, showed the pancreas of rats treated with STZ-NIC. Number of islet cells was found to be decreased and also ratio of acinar to islet cell was not maintained. Deposits of a homogenous eosinophilic material largely occupying the islet and around blood vessels were seen. This could be a localized amyloidosis, which has been documented to occur in the pancreas in many diabetics.

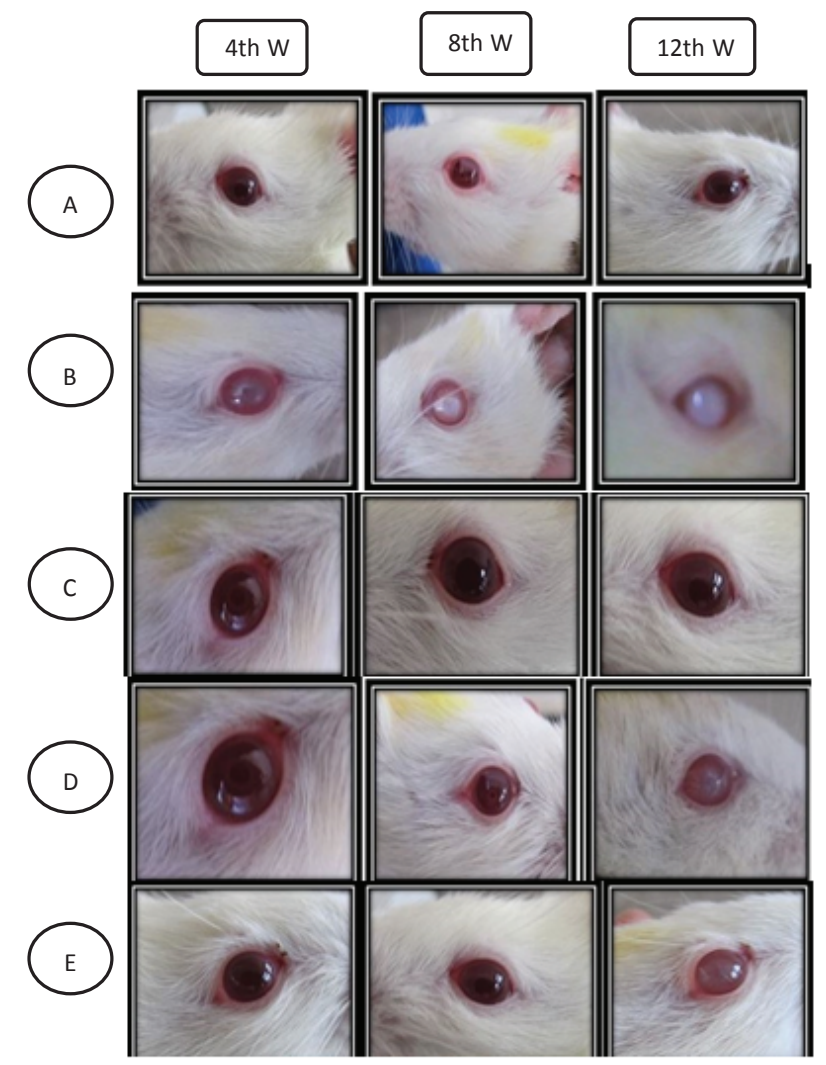

Fig. 3: Changes after treatment till 12th w

(A) Normal control; (B) diabetic control; (C) standard; (D) therapeutic dose; (E) 2X therapeutic dose

May-June 2019
TABLE 4: ESTIMATION OF TOTAL PROTEIN FROM EYE LENS AT THE END OF STUDY

\begin{tabular}{ccc}
\hline Name of group & Treatment given & $\begin{array}{c}\text { Total protein } \\
(\mathrm{g} / \mathrm{dl})\end{array}$ \\
\hline Normal control & $0.1 \% \mathrm{CMC}$ & $\begin{array}{c}1.0212 \pm 0.1333 \\
(\mathrm{n}=8)\end{array}$ \\
Diabetic control & $0.1 \% \mathrm{CMC}$ & $\begin{array}{c}0.2741 \pm 0.0057^{\#} \\
(1.25 \mathrm{ml} / \mathrm{kg} / \mathrm{day}, \mathrm{po})\end{array}$ \\
$\begin{array}{cc}(1.25 \mathrm{ml} / \mathrm{kg} / \mathrm{day}, \mathrm{po}) \\
\text { Standard }\end{array}$ & $\begin{array}{c}\text { Metformin } \\
(150 \mathrm{mg} / \mathrm{kg})\end{array}$ & $\begin{array}{c}0.9100 \pm 0.05151^{\dagger} \\
(\mathrm{n}=7)\end{array}$ \\
Therapeutic dose & Polyherbal & $0.6554 \pm 0.04469^{\mathrm{c} \#}$ \\
& formulation & $(\mathrm{n}=6)$ \\
2X Therapeutic & $(28.71 \mathrm{mg} / \mathrm{kg})$ & \\
dose & Polyherbal & $0.7292 \pm 0.03542^{\dagger}$ \\
& formulation & $(\mathrm{n}=6)$
\end{tabular}

Values are expressed as mean \pm SEM. Statistical analysis was done by using one way ANOVA followed by Tukey's multiple comparison test. $P<0.05$ was considered statistically significant $\left({ }^{c} p<0.05\right)$; ${ }^{\#}$ data compared with normal control; ${ }^{\dagger}$ data compared with diabetic control

In case of pancreas treated with standard metformin, the acinar cells were found to be normal as shown in fig. 4C. The islets were present in adequate proportion and having normal cellularity of beta cells. There was no evidence of infiltration or fibrosis. The pancreas of rats treated with therapeutic dose of polyherbal formulation is shown in the fig. 4D. Presence of few islets of beta cells was observed. Islets were largely occupied by a uniform eosinophilic material and few atrophic cells. Eosinophilic materials also surround the blood vessel. There was slight regeneration of $\beta$ cells. Fig. 4E, shows pancreas of rats treated with $2 \mathrm{X}$ therapeutic dose of polyherbal formulation. The acinar cells appeared to be normal. The islets were present with a large proportion and with smaller volume as compared to diabetic control. There was more regeneration of $\beta$ cells as compared to therapeutic dose and further destruction of the remaining $\beta$ cells in islet appeared to be stopped.

The results of histopathological examination of rat eyes are shown in fig. 5. Fig. 5A showed histopathology of normal control rat eye. The lens material showed deposition of fibrinoid material, and rest shows proteinaceous material. Retinal layers were normal. Fig. 5B, showed eye of rats treated with STZ-NIC. The lens material has hyalinised and fibrinoid material showing changes due to developed and developing cataract. Retinal layers showed degeneration and detachment. The histopathological section of eye treated with metformin showed normal lens material and retinal layers (fig. 5C). A nearly developing opacity and coagulation of lens material was observed in rats 

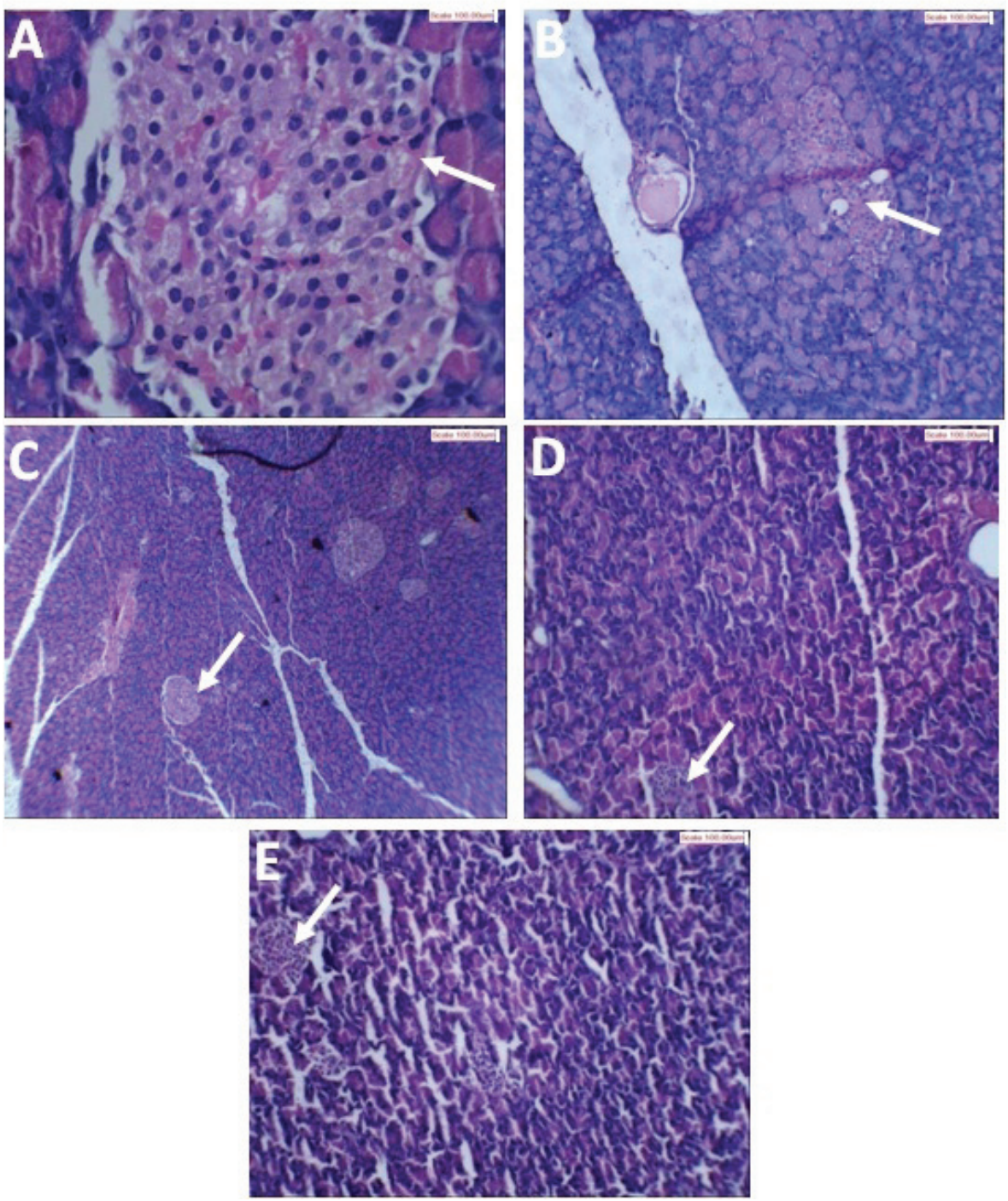

Fig. 4: Histopathological sections of pancreas of rats (scale $100 \mu \mathrm{m}$ )

(A) Normal control; (B) diabetic control; (C) standard; (D) therapeutic dose; (E) 2X therapeutic dose. The arrow indicates the islet region of the section

treated with therapeutic dose of polyherbal formulation along with fibrosis of lens material (fig. 5D). The $2 \mathrm{X}$ therapeutic dose showed early changes of lens material along with hyalinization (fig. 5E).

In the present study, diabetes was induced by administration of STZ and NIC. STZ is an antibiotic and structurally is a glucosamine derivative of nitrosourea. It causes hyperglycaemia mainly by its direct cytotoxic action on the pancreatic beta cells. It also causes alkylation or breakage of DNA strands and a consequent increase in the activity of poly-ADPribose synthetase, leading to decrease in an enzyme in beta cells finally leading to energy deprivation and death of beta cells ${ }^{[24]}$. Here we had administered NIC along with STZ. The NIC is an antioxidant, which exerts protective effect on the cytotoxic action of STZ by scavenging free radicals and causes only minor damage to pancreatic beta cell mass producing type 2 diabetes.

The antidiabetic plant extracts may involve one or more compounds, which decreases blood glucose levels suggesting that the natural constituents could act synergistically to induce a hypoglycaemic effect ${ }^{[15]}$. Combining several medicinal herbs achieved extra therapeutic effect ${ }^{[25]}$. The polyherbal formulation used in the present study is composed of extract of six different herbs having different mechanism of action. The plant guduchi in formulation has antidiabetic activity, as it causes increased entry of glucose into the peripheral tissues and organs like liver. The oral administration of an aqueous root extract is reported to exert a significant reduction in blood glucose and brain lipids, increase in body weight. Also the alcohol extract of guduchi has preventive effect on the development 

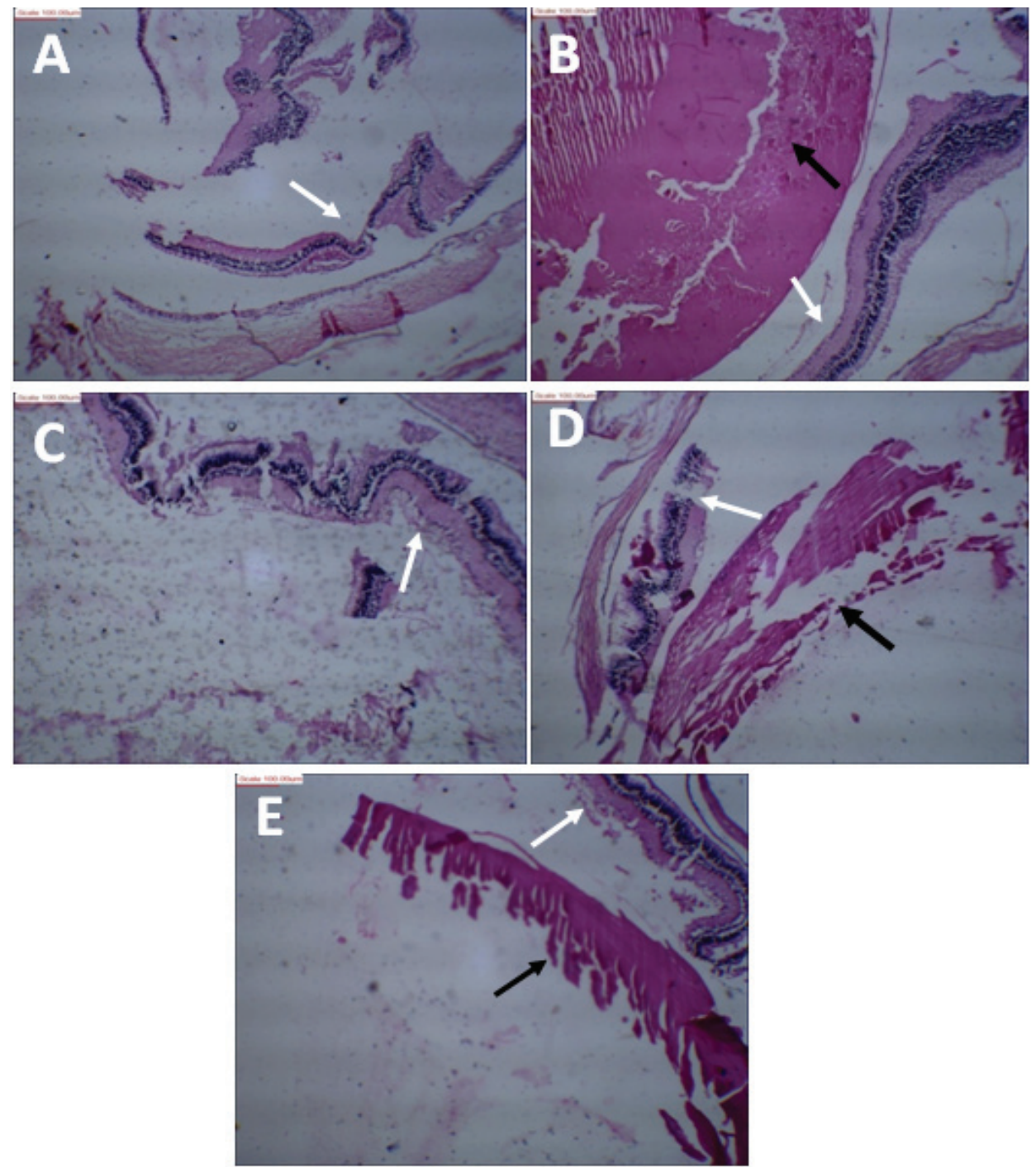

Fig. 5: Histopathological sections of eye (scale $100 \mu \mathrm{m})$

(A) Normal control; (B) diabetic control; (C) standard; (D) therapeutic dose; (E) $2 \mathrm{X}$ therapeutic dose. The white arrow indicates retinal structure and black arrow indicates lens structure

of cataract in alloxan-induced diabetic rats ${ }^{[26]}$. Previous studies on cinnamon suggest it could affect protein phosphorylation dephosphorylation reactions in the intact adipocytes, which helps to reduce sugar level ${ }^{[27]}$. Haridra lowers blood sugar, increases glucose metabolism and potentiates insulin activity more than three fold. Several animal studies have demonstrated that curcumin present in Haridra can overcome insulin resistance and can delay cataract incidence in diabetic patients $^{[28]}$. The studies on fenugreek showed that the hypoglycemic effects of fenugreek is due to presence of the amino acid 4-hydroxyisoleucine in fenugreek seeds. It causes insulin release in rat pancreatic islet cells ${ }^{[29]}$. The seeds may double the regeneration of $\beta$-cells in pancreas ${ }^{[30]}$. The leaves of fenugreek contain high content of lutein and prevent free radical formation. Hence it can be used as a good dietary source of lutein to protect and ameliorate cataract ${ }^{[31]}$. Neem blocks the action of epinephrine on glucose metabolism. It was found that chloroform extracts of Neem showed significant regeneration property of functional $\beta$-cells ${ }^{[12]}$. Piperine, a substance present in Maricha has been found to increase absorption of selenium, B-complex vitamins, beta-carotene, curcumin as well as other nutrients from food ${ }^{[32]}$. Thus effect of combination of all these extract in polyherbal formulation might decrease serum glucose levels, reduces destruction of $\beta$-cells and body weight, also improves protein contents and delays cataract.

Metformin was used as a standard drug in the current study. It acts principally by increasing insulin sensitivity and increase in the peripheral glucose utilization and decrease in hepatic glucose production. The UK Prospective Diabetes Study demonstrated 
a significant survival advantage for type 2 patients started on metformin as first-line therapy ${ }^{[33]}$.

Treatment of polyherbal formulation showed significant decrease in serum glucose level. It may be due to effect of combination of all these extract in polyherbal formulation as discussed above. Metformin-treated animals showed rapid normalization of serum glucose as compared to polyherbal formulation-treated animals.

Polyherbal formulation treatment also prevented the loss in body weight as compared to diabetic control rats. It may be due to amelioration of glycaemic control and structural proteins synthesis ${ }^{[34]}$. Metformin has long been recognized as a suitable first-line agent for type 2 diabetes as it is the only oral hypoglycemic agent associated with no weight gain or even weight reduction $^{[33]}$.

Decrease in serum glucose level and weight loss prevented by the treatment with $2 \mathrm{X}$ therapeutic dose of polyherbal formulation is more as compared to therapeutic dose of polyherbal formulation. In the standard group cataract was not developed. This might be due to increased peripheral glucose utilization ${ }^{[34]}$. Treatment with polyherbal formulation delayed the progression of cataract. After induction of diabetes by STZ-NIC there was development of cataract in diabetic control group. Incidence of cataract was observed from $3 \mathrm{rdw}$ in diabetic control rats while in case of therapeutic dose it was at 10th $\mathrm{w}$ and in case of $2 \mathrm{X}$ therapeutic dose it was at 12th w. This suggested that the polyherbal formulation exerted protective action on cataract and also resulted in delaying progression of cataract. The $2 \mathrm{X}$ therapeutic dose showed greater delay as compared to therapeutic dose.

The lens is made of mostly water and protein. Crystallins are the major structural proteins in the lens accounting for up to $90 \%$ of total soluble protein ${ }^{[35]}$. Protein denaturation has been considered to be the ultimate change that results in lens opacification. The treatment with polyherbal formulation improved the total protein content in eye lenses probably by preventing osmotic stress and subsequent leakage of proteins through the inhibition of aldose reductase (AR) ${ }^{[36]}$. This improvement was more in $2 \mathrm{X}$ therapeutic dose as compared to therapeutic dose. While metformin-treated group of rats showed more improved protein content as it is supposed to have an antioxidant property ${ }^{[37]}$.

In diabetes there is destruction of pancreatic $\beta$-cells. Histopathological examination of pancreas supported presence of islet cells and few foci of regeneration of pancreatic $\beta$-cells. The regeneration of $\beta$-cells was comparatively more in rat pancreas treated with $2 \mathrm{X}$ therapeutic dose. In case of pancreas treated with standard metformin normal cellularity of beta cells was observed.

Histopathological study of eye lenses in normal group and metformin-treated group showed normal lens and retina while diabetic animals showed necrotic changes in lens and retina. The eye lenses-treated with therapeutic and $2 \mathrm{X}$ therapeutic dose showed early changes in the lens material. This also suggests that the polyherbal formulation can help in delaying cataract and it could be dose-dependent.

On the basis of these results, it can be concluded that a combination of glycemic control, regeneration of pancreatic $\beta$-cells, AR inhibition and antioxidant potential could be the possible mechanisms of polyherbal formulation in delaying the cataract. The polyherbal formulation is effective as antidiabetic and delays the progression of cataract in a dose-dependent manner. Moreover, further longer duration studies of polyherbal formulation in chronic models are necessary to assess a potent antidiabetic effect and its effect on diabetic complications.

\section{Acknowledgements:}

Authors thank Nisarga Biotech Pvt. Ltd., Satara for providing sample of polyherbal formulation. Authors also are grateful to Drishti Eye Hospital, Satara and Disha Diagnostic, Satara for providing facilities to carry out research work.

\section{REFERENCES}

1. Mali KK, Dias RJ, Havaldar VD, Mahajan NS. Hypoglycemic activity of Caralluma adscendens in alloxan induced diabetic rats. Int J Chem Sci 2009; 7:517-22.

2. Belhekar SN, Chaudhari PD, Saryawanshi JS, Mali KK, Pandhare RB. Antidiabetic and antihyperlipidemic effects of Thespesia populnea fruit pulp extracts on alloxan induced diabetic rats. Indian J Pharm Sci 2013;75:217-21.

3. Mohan V, Sandeep S, Deepa R, Shah B, Varghese C. Epidemiology of type 2 diabetes: Indian scenario. Indian $\mathrm{J}$ Med Res 2007;125:217-30.

4. Epidemiology of diabetes mellitus [cited 2017 Jan 16]. Available from: https://en.wikipedia.org/wiki/Epidemiology_ of_diabetes_mellitus.

5. Sridhar G, Rao P, Ahuja P. Epidemiology of diabetes and its complications. In: Ahuja MMS, Tripathy BB, Moses SGP, Chandalia HB, Das AK, Rao PV, editors. RSSDI textbook of diabetes mellitus. 1st ed. Hyderabad, India: RSSDI, Research Society for the study of diabetes in India; 2002. p. 95-112.

6. Robbin S, Cotran R, Kumar V. Pathologic basis of disease. 5th 
ed. Bangalore, India: Prism Books Pvt. Ltd.; 1994. p. 913-18.

7. Kakehashi A. Diabetic Ocular Complications in the SDT Rat. Open Diabetes J 2011;4:37-40.

8. Mohan H. Textbook of Pathology. 4th ed. New Delhi: Jaypee Brother's Medical Publisher; 2000. p. 842-50.

9. Kyselova Z, Stefek M, Bauer V. Pharmacological prevention of diabetic cataract. J Diabetes Complications 2004;18:12940.

10. Pollreisz A, Schmidt-Erfurth U. Diabetic cataractpathogenesis, epidemiology and treatment. J Ophthalmol 2010;2010: 608751.

11. Agarwal S, Tamrakar B, Paridhari M. Clinically useful herbal drugs. 1st ed. Delhi: Ahuja Publishing House; 2005. p. 97.

12. Kant S. Sahu M, Sharma S, Kulkarni K. Effect of Diabecon (D-400), an Ayurvedic herbomineral formulation on diabetic retinopathy. Indian J Clin Pract 2002;9:49-56.

13. Ogbonnia S, Mbaka G, Adekunle A, Anyika E, Gbolade O, Nwakakwa N. Effect of A poly-herbal formulation, Okudiabet, on alloxan-induced diabetic rats. Agric Biol J N Am 2010;1:139-45.

14. Tushar K. Debasis D, Chatterjee K, Ali K, Ghosh D. Effect of Diashis, a Polyherbal formulation, in streptozotocin-induced diabetic male albino rats. Int J Ayurveda Res 2010;1:18-24.

15. Thakkar N, Patel J. Pharmacological evaluation of glycoherb:Apolyherbal formulation on streptozotocin induced diabetic rats. Int J Diabetes Dev Ctries 2010;30(1):1-7.

16. Palsamy P, Subramanian S. Resveratrol, A natural phytoalexin, normalizes hyperglycemia in streptozotocin-nicotinamide induced experimental diabetic rats. Biomed Pharmacother 2008;62:98-605.

17. Shin J, Seol I, Son C. Interpretation of Animal Dose and Human Equivalent Dose for Drug Development. J Korean Orient Med 2010;31(3):1-7.

18. Paget G, Barnes J. Toxicity tests. In: Lawrence DR, Bacharach AL, editors. Evaluation of drug activities; Pharmacometrics. New York: Academic Press; 1964. p. 161.

19. Rooban BN, Lija Y, Biju PG, Sasikala V, Sahasranamam V, Abraham A. Vitexnegundo attenuates calpain activation and cataractogenesis in selenite models. Exp Eye Res 2009;88:575-82.

20. Pandit RS, Kelkar AS, Bodhankar SL. Retinal and lens protective effect of sitagliptin in streptozotocin induced type-I diabetic wistarrats. Biomed Aging Pathol 2013;3:65-73.

21. Valavala V, Vangipurapu R, Banam V. Effect of mustard (Brassica juncea) leaf extract on streptozotocin-induced diabetic cataract in Wistar rats. J Food Biochem 2011;35:10924.

22. Shi Q, Yan H, Li M, Harding J. Effect of a combination of carnosine and aspirin eye drops on streptozotocin-induced diabetic cataract in rats. Mol Vis 2009;15:2129-38.
23. Sensi M, Pricci F, Pugliese G, Rossia M, Petruccib A, Cristina A. et al. Role of advanced glycation end-products (AGE) in late diabetic complications. Diabetes Res Clin Pract 1995;28:9-17.

24. Srinivasan K, Ramarao P. Animal models in type 2 diabetes research: An overview. Indian J Med Res 2007;125:451-72.

25. Parasuraman S, Thing G, Dhanaraj S. Polyherbal formulation: Concept of Ayurveda. Pharmacogn Rev 2014;8(16):73-80.

26. Krishna K, Jigar B, Jagruti P. Guduchi (Tinospora cordifolia): Biological and Medicinal properties, a review. Internet J Altern Med 2009;6:1-5.

27. Al-Jamal A. Rasheed I. Effects of cinnamon (Cassia zelynicum) on diabetic rats. Afr J Food Sci 2010;4:615-17.

28. Aggarwal N, Shishu. A review of recent investigations on medicinal herbs possessing anti-diabetic properties. J Nutr Disorders Ther 2011;1:1:1-10.

29. Ethan B, Ulbricht C, Kuo G, Szapary P, Smith M. Therapeutic applications of fenugreek. Altern Med Rev 2003;8(1):1-8.

30. Khalil EAM. Biochemical and histopathological studies on the influence of aqueous extract of fenugreek seed (Trigonella foenumgraecum) on alloxan diabetic male rats. J Hosp Med 2004; 15:83-94.

31. Thammanna SS, Dinesha R, Harsha R, Leela S. Free radical scavenging activity of lutein - isolated from methi leaves (Trigonella foenumgraecum). Int J Pharm Pharm Sci 2010;2:113-17.

32. Chioma O, Victor N, Emeka G. Toxicological Assessments of Piper nigrumon Alloxan Induced Diabetic Rat. J Toxicol Sci 2014;6:30-34.

33. Tripathi KD. Essentials of Medical Pharmacology. 6th ed. New Delhi: Jaypee Brothers Medical Publishers; 1999. p. 254-55.

34. Balamurugan R, Ignacimuthu S. Antidiabetic activity of $\gamma$-sitosterol isolated from Lippianodi flora L. in streptozotocin induced diabetic rats. Eur J Pharmacol 2011;5:3-9.

35. Jain AK, Lim G, Langford M, Jain SK. Effect of high-glucose levels on protein oxidation in cultured lens cells, and in crystalline and albumin solution and its inhibition by vitamin B6 and N-acetylcysteine: it's possible relevance to cataract formation in diabetes. Free Radic Biol Med 2002;33;1615-21.

36. Chandel H, Pathak A, Tailang M. Polyherbal formulations for antidiabetic therapy. Int J Pharm Sci 2011;15:226-8.

37. Obi BC, Okoye TC, Okpashi VE, Igwe CN, Alumanah EO. Comparative study of the antioxidant effects of metformin, glibenclamide, and repaglinide in alloxan-induced diabetic rats. J Diabetes Res 2016;2016:1-5. 